\title{
KRONIK
}

\section{Istikrar Programı ve Mali Kriz}

Prof. Dr. Oğuz Oyan, A.Ü. Siyasal Bilgiler Fakültesi Öğretim Üyesi

IMF ile Türkiye arasında imzalanan 3 ylllık istikrar programınun (stand-by) ikinci yllına girildi. Henüz birinci yllında büyük bir yol kazasına uğrayan bu programın başarısına ilişkin belirsizlikler büyürken, çeşitli çevrelerin programa olan güvenleri de sarsılmı̧ durumda.

Uygulanan program her ne kadar bir "anti-enflasyonist istikrar programi" olarak adlandınlmıs olsa da, programın tek hedefinin enflasyonu düşürmekle sınırlı olduğu söylenemez. İtikrar hedefinin arkasında, Dünya Bankasi'nın (WB) yoğun gözetim ve müdahalelerini içeren bir yapısal uyum programı (YUP) bulunmakta. "Yapısal uyum" amaçlı düzenlemelerin, Türkiye ekonomisi ve kamu ekonomisi açsından orta ve uzun vadede çok daha önemli sonuçlar doğurması olasılığı da artık daha genis çevrelerce farkedilmeye başlandı.

Programın ilginç bir özelliği, Hazine Müsteşarlı̆̆ından sorumlu Devlet Bakanı ile TC Merkez Bankası Başkanı tarafından imzalanan çok sayıda "niyet mektubu" vasıtasıyla işlerlik kazanması. 2001 yılında yürürlüğe giren Sekizinci Beş Yllık Kalkınma Planı ile bağları kopuk olduğu gibi, yıllık program ve bütçelerle tam uyum halinde olması da öncelikli görülmeyen niyet mektupları, Türkiye ekonomisinin üç yıl ve sonrasındaki kaderini sıkı bir biçimde belirleyen ama idare hukukunda ve Anayasada karşıllı̆ı olmayan yeni bir ekonomik anayasa kimliğini taşımaya başladılar. Gerçekte Hazine Müsteşarı ile TCMB Başkanı'nun yürüttüğü, Hükümetin ise "destek verdiğinin" ifade edildiği bu radikal programlar acaba Türkiye'nin gerçek sorunlannı çözebilecek mi?

9 Aralık 1999'da Ana Niyet Mektubunun imzalanmasıla yürürlüğe giren IMF'nin geleneksel istikrar politikası Türkiye'nin koşullarına uygun muydu? IMF'nin klişeleşmiş stand-by programları, hızlı bir ekonomik büyümeyle aşırı ısınmış, cari işlem açıkları büyümüs ve enflasyonu hızlanmıs bir ekonomiyi talep yönetimine dayalı bir soğutma sürecine sokmayı ve dış yükümlülüklerin yerine getirilmesi için de dış kaynak sağlamayı hedefler. Oysa, Türkiye 1999'da negatif büyüme gerçekleştirmiş, önemli bir cari açık vermeyen ve enflasyonu kronik olarak yüksek seyreden bir ckonomidir. (Korkut Boratav) Döviz çıasına dayalı IMF programı, 1999 ylinda olmayan cari açık sorununu 2000 yllında yaratarak kendi yarattığ soruna çözüm aramaya yöneldi. Ancak henüz bir çözüm bulunamadan $22 \mathrm{Kasım}-6$ Aralık arasında bir mali kriz patlak verdi.

Krizin oluşum nedenleri arasında birinci sırayı, büyüyen cari açıkların mali 
sistem ve spekülatif yabancı sermayede yaratth̆g güvensizlik almakta. Cari açıklar büyürken programın kaynak sorunlarının da büyüyor olması, spekülatif bir atak için ortamı elverişli bir duruma getirmişti. Dolayısıyla, mali krizi son vuruşu yapana bakarak açıklamak yüzeysel kalmaktadır.

Ancak alttan alta çalışan ikinci bir nedenden daha söz edilcbilir. 1999 Ekim sonundan itibaren, IMF ile imzalanacak anlaşmanın da olumlu etkisini arkasına alarak, nominal faiz hadlerinde çok hızlı düşüşler sonucunda 2000 yılınun ilk 11 ayında ortalama yüzde 38 oranının tutturulması ve reel faizlerin sıfır veya negatif olması (ki döviz girişine bağlanan TL arzındaki artışın da bu sonucu vermesi beklenmeliydi), hem mali sistemi hem de karlarını giderek devletin borçlanma politikası üzerinden sağladıkları yüksek faiz transferleriyle gerçekleştiren büyük sermaye şirketlerini de zora sokacağı açıktı. Dolayısıyla mali sistemin, yakaladığı ilk firsatta, Hazine'yi daha yüksck faiz ödemeye zorlayacak bir kol güreşi momentumunu beklediği hesaba katılmalıydı.

Kasım 2000 krizi, Türkiye Cumhuriyeti tarihinde görülmemiş büyüklükte bir IMF yardımının harekete geçirilmesiyle yatıştınlmıştır. Ancak buna rağmen faiz hadleri Ocak 2001'de kriz öncesi ortalamasının yüzde 70) kadar üzerinde seyretmektedir. Yükselen nominal faiz hadleri ile yavaşlayan fiyat artı̧ları arasında açlan makas, ancak yüksck reel faizli eski saadet zincirine yeniden dönülerek şimdilik "istikrarın" kurtarıldığını göstermektedir. Bununla birlikte, mali krizin reel ekonomi üzerindeki olumsuz etkileri tüm ağırlı̆̆ın

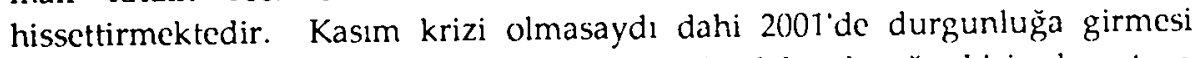
beklenen ekonomik etkinlikler, krizin etkisiyle daha da ağır biçimde ortaya çıkmaktadır.

Programın hedeflerinin birinci yll sonundaki gerçekleşmelerine bakıldığında, hedeflerin hiçbirinin gerçckleştirilemediği görülmektedir. Programın öngördüğü hedeflerin başında gelen ve çok sayıda araçla desteklenen TEFE ve TÜFE'de gerçekleşmeler hedeflerin yüzde 65 üzerinde kalmıştır. Cari ą̧k 2.9 milyar dolar (revize edilmiş haliyle 4.8 milyar dolar) olarak hedeflenmişken, gerçekleşme beklentisi 9.6 milyar dolardır. Bütçe açı̆̆ 11.5 katrilyon olarak hedeflenmişken, gerçekleşen denge 12.8 katrilyondur. Özelleştirme geliri hedefi 7.5 milyar dolar, gerçckleşme 3.7 milyar dolardır. Ithalat, ihracat ve dıs ticaret dengesi gerçekleşmeleri hedeflerle tamamen ilişkisizdir. Kamu kesimi açığının GSMH'ya oran yüzde 15 olarak hedeflenmişken, gerçckleşme yüzde 19'dur. Hedefe en yakın düşen gerçekleşme GSYIH artışı olmakla birlikte burada dahi bir sapma görülmektedir. Kaldı ki, 2001 yilı için revize edilmiş büyüme hedefinin dahi tutturulması mümkün gözükmemcktedir.

Hedeflerden bu sapmalar, programın öngördüğu tüm önkoşullar harfiyen yerine getirilmis olmasına rağmen ortaya çkmışır. Kamu ekonomik yönetiminin, diğer hedeflerden farklı olarak inisiyatif kullanabileceği 
özelleştirme hedefinde "gecikmesi", olağanüstü vergi gelirlerinde hedeflerin üzerinde artı̧̧ sağlanması yoluyla fazlasıyla telafi edilmiş̧tir. Dolayısıyla, Kasım 2000 krizini programa sadık kalmayan veya geciken kamu ekonomik yönetimine (bürokrat veya siyasilere) fatura etmenin hiçbir haklı gerekçesi bulunmamaktadır.

2001 başlannda Türkiye ekonomisi, 1999 sonunda bulunduğu noktadan çok daha zor bir duruma sürüklenmiştir. 1999 sonunda iç denge sorunları yaşayan Türkiye ekonomisi, 2000 sonundan itibaren hem iç hem de dıs denge sorunlarını birlikte yaşamaya başlamıştır. Böylesine bir çifte kıskaç içine ilk kez giren Türkiye ekonomisi ve bu tür bir sorunla başetme deneyimi olmayan ekonomi bürokrasisi için herşey şimdi daha şetrefil ve belirsiz gözükmektedir. 